\title{
BRIDGES ACROSS THE MEDITERRANEAN SEA: AN INTRODUCTION TO THE MAGHREB-SOUTHERN EUROPE MIGRATION SYSTEM
}

\author{
AleXANDre Abreu ${ }^{1}$ \\ JoÃo Diogo Mateus ${ }^{2}$
}

\begin{abstract}
The current geopolitical importance of the Mediterranean is heightened by the fact that it is both a dividing physical barrier between a developed Europe and a chronically peripheral Africa and one of the main structuring corridors for international migration. This note builds on the assumption that the Maghreb-Southern Europe migratory flows are best analysed in a "migration systems" approach and makes a contribution to the awareness of the history and present characteristics of the flows within this particular system. The note is divided into five sections: Section 1 further specifies the object of the note; Section 2 provides a brief historical account of the main periods and events of relevance to the dynamics of this migration system; Section 3 is a quantitative analysis of the stocks and flows of North African immigration to European countries in the recent past; Section 4 looks into these flows in further detail, seeking to identify some of their recent characteristics; finally, Section 5 identifies some foreseeable (economic, institutional, demographic,...) developments that are likely to affect the future dynamics of the system.
\end{abstract}

Key words : Migration; Mediterranean; Southern Europe; Maghreb; migration systems

Resumo - PONTES NO MAR MEDITERRÂNEO: UMA INTRODUÇÃO AO SISTEMA MIGRATÓRIO do Magrebe - Europa Do Sul. A actual importância geopolítica do Mediterrâneo prende-se com o facto de constituir, simultaneamente, uma barreira divisória entre uma Europa desenvolvida e uma África cronicamente periférica e um dos principais corredores estruturantes das migrações internacionais. Esta nota considera que a abordagem segundo a teoria dos sistema migratórios é a mais profícua para a análise dos fluxos migratórios entre o Magrebe e a Europa do Sul e visa contribuir para o conhecimento da história e características dos fluxos no interior deste sistema migratório particular. Para tal, está dividida em cinco secções: a primeira

1 Economist and research assistant in the Project "Reinventing Portuguese Metropolises: Migrants and Urban Governance" [hosted by the Centre of Geographical Studies of the University of Lisbon, funded by the Fundação para a Ciência e Tecnologia (POCTI/38599/GEO/2001) and co-ordinated by Maria Lucinda Fonseca]. E-mail: alexaabreu@vis.fl.ul.pt

2 Geographer and research assistant in the same Project. E-mail: diogomateus@vis.fl.ul.pt 
secção especifica o objecto da nota; a Secção 2 constitui uma breve apresentação histórica dos períodos e eventos mais relevantes para a dinâmica deste sistema migratório; a Secção 3 é uma análise quantitativa dos stocks e fluxos da imigração magrebina para os diversos países europeus; a secção 4 procura identificar algumas das características recentes desses fluxos; finalmente, a Secção 5 apresenta alguns dos desenvolvimentos previsíveis (económicos, institucionais, demográficos,...) que mais provavelmente afectarão a dinâmica futura do sistema.

Palavras-chave : Migrações; Mediterrâneo; Europa do Sul; Magrebe; sistemas migratórios

\section{INTRODUCTION}

The goal of this paper is to provide a brief introduction to the history and characteristics of the trans-Mediterranean migratory flows, particularly those originating in the Maghreb and destined for Southern Europe.

It wasn't until the second wave of the globalisation process, in which the widening of the gap between central and peripheral regions took place alongside significant migration flows in the South-North direction ${ }^{3}$, that the current geopolitical role of the Mediterranean came to be defined: that of acting as a dividing barrier between a central and developed Europe and a chronically peripheral Africa, while serving as one of the main structuring "corridors" of the world migratory system. It is as such that the Mediterranean Sea has on occasions been likened, or compared, to the Rio Grande along the US-Mexico border, insofar as, in both cases, a self-evident cleavage (both in terms of living standards and of the role played in the capitalist world-system) and, more recently, a series of legal and security barriers (which seek to curb the migratory potential arising from that cleavage) have added to a pre-existent natural barrier ${ }^{4}$.

The Mediterranean has thus come to play a fundamental role as a stepping-stone for migrants from throughout the African continent (including not just the Maghreb, but also countries south of the Sahara) and destined for the whole of Western Europe (not just Southern Europe). This diversity of origins and destinations must to be taken into account in any analysis of the trans-Mediterranean migratory flows, very much in the same way as one must not ignore the relevance of certain other specific migratory flows, such as Egyptian or Turkish emigration, which, albeit following different logics, also occur in the Mediterranean region.

3 Unlike the first wave of the globalisation process, in which the most significant migration flows took place in the North-South direction, e.g., from Europe to Argentina, Australia and Brazil (Solimano, 2001; Castles and Miller, 2003).

4 BECK and DE MAS (2001), in particular, explicitly analyse the similarities and differences between the Rio Grande and the Strait of Gibraltar. Alongside the aforementioned general similarities, these authors highlight the following main differences: (1) a more recent significant migration history in the case of the Mediterranean; (2) larger migratory flows in the case of the Rio Grande (even though the comparison made in this case is only with the Morocco-Spain migratory flows); (3) the existence of a greater "development gap" in the case of the Strait of Gibraltar; and (4) the fact that Mexican emigrants going to the US began by settling in rural areas and only started to settle in urban areas at a later stage - exactly the opposite of the general trend of the Moroccan emigration to Spain 
For reasons of space as well as for convenience of analysis, the ambit of this paper is thus confined to the migratory flows from the Maghreb to Southern Europe. This methodological option has to do with a number of common features - in terms of history, economics and characteristics of the migratory flows themselves - that, as we shall see, call for a separate analysis. Even though the Maghreb region can be seen as including Libya as well, in this paper - following MGHARI (2000) - the analysis is confined to its three central countries ${ }^{5}$ (Morocco, Algeria and Tunisia), since, for instance, Libya has a long-standing tradition of immigration ${ }^{6}$, rather than emigration.

Likewise, in the context of this paper, "Southern Europe" is seen as including Spain, Italy and France, while deliberately excluding, for various reasons, other countries that are de facto situated in Southern Europe. That is, for instance, the case of Portugal, a country whose long history of emigration has, from the 1960s onwards, been accompanied by an incorporation in the world migratory dynamics by way of an essentially postcolonial immigration and, more recently, by increasingly important migratory flows from Eastern Europe, but which has not come to play any significant role as a destination for North African migration; or the Balkan countries, which despite being located in the Southern part of the Northern shore of the Mediterranean Sea, can for all intents and purposes be considered as peripheral or semi-peripheral countries within the dynamics of the global economy. That fact, along with the recent episodes of political strife, has had as its consequence that these countries have in recent times been at the origin of considerable emigration flows, not assuming any relevance as destination areas for international (particularly North African) migration.

\section{A BRIEF HISTORY OF NORTH AFRICAN MIGRATION FLOWS}

The history of North African emigration is inextricably linked with the region's colonial past. Morocco, Algeria and Tunisia, all former French colonies (with the exception of Western Sahara, a Spanish protectorate up until 1976, whose independent status is a matter of dispute to this day) have for long been the source of significant migration flows to the metropole - which did not decrease in scale (on the contrary) after their independence in 1956 (in the case of the two former) and 1962 (in the case of Algeria, following the war of independence).

The emergence of other Southern European countries as important destinations for North African emigration took place in the 1970s and was largely a result of the general tendency towards stricter immigration controls which then began to prevail in France (and other Northern European countries). This change in the general orientation of the immigration policies - which was not followed in the other Southern European until after some time -, along with a series of structural transformations then taking place in these latter countries (in all or some of the cases: increase in the pace of the catching-up process, European integration, democratisation, etc. (FONSECA, 2002)) brought about some very significant changes in the magnitude and characteristics of the migratory flows to the various European countries.

5 Incidentally, the word "Maghreb" comes from the Arab for "land of the setting sun".

6 Most of these immigrants come from the Sahel region or from countries south of the Sahel (BensaÂD, 2002; CAStles and Miller, 2003). It is worth pointing out that, by 2000, the total immigrant population in Libya reached 570,000: $10.8 \%$ of a total population of 5,290,000 (Source: United Nations Population Division - Department of Economic and Social Affairs Internet site). 
Hence, for analytical purposes, the following three major phases in the history of North African emigration in the last century can be identified:

\section{The colonial period (until the independence in 1956/1962)}

As might be expected, North African emigration during the colonial period consisted chiefly of flows to the metropole. The most substantial share originated in Algeria - which arguably had to do with the fact that this was the first of the three countries to be colonised (1830) and with the special ties that bound Algeria and France throughout the colonial era. Although these flows can be traced back to the 19th century, it was not until the outbreak of World War $\mathrm{I}^{7}$ that they would become truly significant. This conflict - arguably the greatest and most tragic historical example of a "labour-intensive" war gave rise to the recruitment and forced migration of half a million North Africans (Algerians, Moroccans and Tunisians) by the French metropolitan authorities. These North African nationals were destined both for the trenches (where in fact they suffered heavy casualties) and for the supporting industrial effort. Utilitarian reliance upon this source of cheap labour did not come to a halt after the end of the conflict (due to the shortage of labour for post-war reconstruction): it was not until the economic crisis of the 1930s that massive numbers of North Africans were to be repatriated. At the time, colonial labour was brought in and repatriated purely according to the needs of the metropole.

With the outbreak of World War II, the cycle began yet again, only this time reliance on colonial labour corresponded mainly to the reconstruction phase, not the actual conflict. By the mid-1950s, some 220,000 Algerians, 20,000 Moroccans and 5,000 Tunisians were estimated to have settled in France.

\section{From independence until 1974}

Movement towards independence in the Maghreb began in the 1950s and concluded by 1956, in the case of Morocco and Tunisia, and 1962, in the case of Algeria. The joint effect of their independence, which stimulated post-colonial emigration (Mghari, 2000), and of the unrecorded dynamics of economic growth that followed World War II in most Western economies, gave rise to a very substantial increase in North African emigration. It is worth recalling that the economic expansion of the "golden decades" between the end of World War II and the crisis of the 1970s was probably also the most important structural determinant of the massive Portuguese migratory flows of the period, which were, at the time, in many ways similar to the flows originating in the Maghreb ${ }^{8}$.

Two of the most distinctive features of the North African migratory flows in this period were the increase in the diversity of the destinations (which were no longer solely destined for France) and the more organised and formal nature of the migratory processes. Bilateral agreements were signed between the various countries of the Maghreb and several European countries (France, Belgium, the Netherlands, Germany), which led to the creation of specialized teams in the sending countries whose mission was to recruit local workers (CEGARRA, 2002). These immigration flows from the Maghreb,

\footnotetext{
8 For instance, insofar as both were chiefly destined for the secondary labour market. To this day, the Portuguese and Algerian communities dispute the title of the largest immigrant community in France.
}

7 According to official figures cited in MghaRI (2000), 12,000 Algerians lived in France by 1912 . 
along with those from the semi-peripheral European economies (e.g., Portugal and Poland) provided the abundance of labour that facilitated the process of reconstruction and growth. However, possibly due to the fact that these flows took place chiefly within the ambit of bilateral agreements, the truth is that the migratory flows from the three Maghreb countries under scrutiny in this paper were not affected in the same way (Mghari, 2000). The main differences between the three were the following: Moroccan emigration experienced the greatest expansion, followed by the Tunisians. Algerian emigration, which had long been the most significant of the three, experienced the smaller relative increase. With regard to the territorial dispersal of the three communities, a similar distinction can be drawn: Moroccan emigrants began to settle in other European countries (e.g., Belgium and the Netherlands), whereas the Algerians and, to a lesser extent, the Tunisians, continued to settle mostly in France. Nevertheless, even in the case of the Moroccans, North African emigration to the other Southern European countries (Italy and Spain) at the time was still relatively unimportant. It was not until the economic crisis of the 1970s that this change would come about.

\section{From the mid-1970s to the present day}

The 1970s saw the end of the golden years of post-war economic growth. The 1973 oil crisis gave rise to a long period of stagnation, in which unemployment and inflation coexisted in a process that came to be known as "stagflation". Against a background of widespread unemployment and price escalade, immigration quickly became "undesirable" - a scapegoat for economic strife. Thus, in 1974, France and several other Northern European countries took a series of legal measures aimed at "reinstating control over the flows" and "discouraging immigration", largely in response to recrudescent anti-immigration stances amidst the general public. Due to the lack of receptiveness on behalf of France and Northern Europe as much as to their own characteristics at the moment (greater ease of entry, geographical proximity and acceleration of the catching-up process), other Southern European countries such as Spain or Italy quickly positioned themselves as privileged destinations for North African emigration, a position they held on to this day.

This brief historical account illustrates the fact that the management of the migration flows by the metropolitan and post-metropolitan economies has been pragmatic and utilitarian throughout: relative "openness" to immigration in the periods of economic expansion and increased demand for labour; and stricter border controls and the discouragement of immigration - along with the dissemination of the "immigration as burden" discourse - at times of recession and crisis. In turn, as might be expected, the migrants themselves have responded strategically to the institutional (legal framework, effectiveness of policing) and market (demand for labour) changes with which they are faced, in a process of permanent adjustment (BOUBAKRI, 2001).

\section{A QUANTITATIVE ANALYSIS OF THE SIZE AND CHARACTERISTICS OF THE RECENT MIGRATORY FLOWS FROM THE MAGHREB}

As we have seen, the economic, institutional and political changes that have taken place on both sides of the Mediterranean over the past 30 years have played a crucial role in the rearrangement of the migratory flows between the two ends of this migration system. The statistical analysis of these flows reveals some of the recent changes in the size and characteristics of human movements between the two continents. 
The population of North African origin residing abroad is estimated at 3,000,000 people, of which 2,100,000 are documented immigrants in Europe. However, it is estimated that as much as 80 per cent of those 3,000,000 do in fact reside in Europe (whether in a documented or undocumented situation). Of these, roughly one half are Moroccans and just under one third Algerians (MGHARI, 2000). The available statistical data indicates that North African immigrants are mostly concentrated in France, Spain and Italy, even though significant communities are also present in Belgium and the Netherlands 9 .

Tables 1 and 2 provide a picture of the evolution of documented North African immigration in the 1990s, by receiving country ${ }^{10}$. Among the five countries included in the tables, only in Italy and Spain was there an increase in the stock of immigrants from these countries between 1995 and 2000 - an indication of these two countries' emergence as major destinations for migrants. At a time when few doubts remain with regard to the

Table 1 - Stocks and inflows of North African documented immigrants by receiving country and nationality, 1990-2000.

Quadro 1 -Stocks e fluxos de imigrantes legais provenientes do Norte de África, por país de destino e nacionalidade, 1990-2000.

('000/\% of total Non- EU immigrants/rank)

\begin{tabular}{|c|c|c|c|c|c|c|c|c|c|c|c|c|c|c|c|c|c|c|}
\hline & \multicolumn{9}{|c|}{ Stocks } & \multicolumn{9}{|c|}{ Inflows } \\
\hline & \multicolumn{3}{|c|}{1990} & \multicolumn{3}{|c|}{1995} & \multicolumn{3}{|c|}{2000} & \multicolumn{3}{|c|}{1990} & \multicolumn{3}{|c|}{1995} & \multicolumn{3}{|c|}{2000} \\
\hline & ‘000 & $\%$ & rank & ‘000 & $\%$ & rank & ‘000 & $\%$ & rank & '000 & $\%$ & rank & '000 & $\%$ & rank & ' 000 & $\%$ & rank \\
\hline \multicolumn{19}{|l|}{ France } \\
\hline Morocco & 572,7 & 25,1 & 3 & \multicolumn{3}{|c|}{ n.a. } & 504,1 & 24,4 & 2 & 18,2 & 18,5 & 1 & 6,6 & 13,5 & 2 & 16,9 & 18,8 & 1 \\
\hline Algeria & 614,2 & 26,9 & 2 & \multicolumn{3}{|c|}{ n.a. } & 477,5 & 23,1 & 3 & 12,9 & 13,1 & 2 & 8,4 & 17,2 & 1 & 12,4 & 13,8 & 2 \\
\hline Tunisia & 206,3 & 9,0 & 6 & \multicolumn{3}{|c|}{ n.a. } & 154,4 & 7,5 & 7 & 4,3 & 4,4 & 4 & 1,9 & 3,9 & 6 & 5,6 & 6,2 & 4 \\
\hline Italy & & & & & & & & & & \multicolumn{3}{|c|}{ (1998) } & \multicolumn{3}{|c|}{ (1999) } & & & \\
\hline Morocco & 78 & 12,3 & 1 & 94,2 & 11,4 & 1 & 159,6 & 12,9 & 1 & 7,3 & $6,6^{*}$ & 2 & 24,9 & $9,3^{*}$ & 2 & 24,7 & $9,1^{*}$ & 2 \\
\hline Tunisia & 41,2 & 6,5 & 4 & 40,5 & 4,9 & 5 & 45,7 & 3,7 & 7 & 1,5 & $1,3 *$ & 12 & 5,8 & $2,2^{*}$ & 8 & 6,8 & $2,5^{*}$ & 8 \\
\hline \multicolumn{19}{|l|}{ Spain } \\
\hline Morocco & 11,4 & 10,0 & 7 & 74,9 & 28,3 & 2 & 199,8 & $22,3^{*}$ & 1 & \multirow{2}{*}{\multicolumn{3}{|c|}{$\begin{array}{l}\text { n.a. } \\
\text { n.a. }\end{array}$}} & \multirow{2}{*}{\multicolumn{3}{|c|}{$\begin{array}{l}\text { n.a. } \\
\text { n.a. }\end{array}$}} & \multirow{2}{*}{\multicolumn{3}{|c|}{$\begin{array}{l}\text { n.a. } \\
\text { n.a. }\end{array}$}} \\
\hline Algeria & & n.a. & & & n.a. & & 13,8 & $1,5^{*}$ & 15 & & & & & & & & & \\
\hline Belgium & & & & & & & & & & \multicolumn{3}{|c|}{ (1991) } & & & & & & \\
\hline Morocco & 141,7 & 40,1 & 2 & 140,3 & 39,5 & 2 & 106,8 & $12,4^{*}$ & 3 & 3,4 & 11,6 & 3 & 3,6 & 13,6 & 3 & 5,7 & 14,6 & 3 \\
\hline Algeria & 10,7 & 3,0 & 13 & 9,5 & 2,7 & 13 & 7,7 & $0,9^{*}$ & 14 & \multicolumn{3}{|c|}{ n.a. } & \multicolumn{3}{|c|}{ n.a. } & \multicolumn{3}{|c|}{ n.a. } \\
\hline Netherlands & & & & & & & & & & \multicolumn{3}{|c|}{ (1991) } & & & & & & \\
\hline Morocco & 156,9 & 30,3 & 2 & 149,8 & 28 & 2 & 111,4 & 23,9 & 1 & 8,9 & 14,0 & 2 & 3,1 & 5,9 & 4 & 4,2 & 6,1 & 4 \\
\hline Tunisia & 2,6 & 0,5 & 12 & 1,9 & 0,4 & 12 & 1,3 & 0,3 & 11 & \multicolumn{3}{|c|}{ n.a. } & \multicolumn{3}{|c|}{ n.a. } & \multicolumn{3}{|c|}{ n.a. } \\
\hline
\end{tabular}

*\% of the total immigrants.

SOURCE: Adapted from OECD (2002).

9 In Portugal, North African nationalities can not be considered significant in terms of migratory flows: in 2001/2002 for instance, only 1,384 permanence permits were granted to Moroccan citizens, a mere $0.8 \%$ of the total 169,953 permits granted up until October 31st, 2002 (Source: Foreigner's and Borders Office, Internet site).

${ }_{10}$ All statistical data in sections 3 and 4 was taken from OECD (2003), unless otherwise stated. 
Table 2 - Legalization of North African immigrants and naturalizations by receiving country and nationality, various years.

Quadro 2 - Legalização e naturalização de imigrantes provenientes do Norte de África, por país de destino e nacionalidade, vários anos.

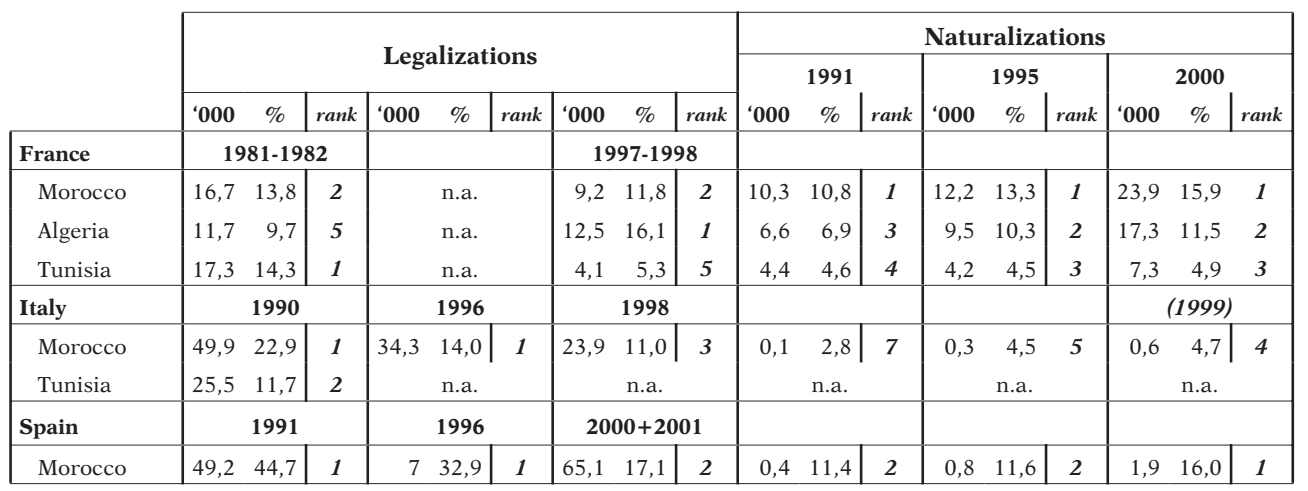

SourCE: Adapted from OECD (2002).

fact that undocumented immigration is rising in Europe, it is important to bear in mind that official statistical records provide but a foggy picture of the true size and characteristics of the actual migration flows: other approaches and techniques are needed as complements ${ }^{11}$.

In France, a country in which undocumented immigrants accounted for 5.6 per cent of the total population in 2000, 60 per cent of the new entries from outside the European Economic area in that year came from Northern Africa. The Algerians are the largest and longest-standing immigrant community, largely due to the long-standing nature and sheer volume of the migratory flows from this country, as well as to the special nature of its historical ties with France. However, there has been a negative variation between 1982 and 1999 (-44.4 per cent) in the number of documented Algerian residents - relegating this nationality to second place behind the Moroccans (who have also decreased in number, although more recently and to a lesser extent). This negative variation was not due to particularly significant outflows: rather, it was a consequence of the crucial role played by the naturalisation of immigrants in this country ${ }^{12}$.

Almost 65,000 immigrants took advantage of the 1997/1998 legalization campaign for undocumented immigrants. For statistical purposes, these immigrants were considered as new entries. The Algerians and the Moroccans were the two most numerous nationalities to benefit from the process, which is a clear indication of their predominance among the undocumented immigrant population as well. By 1990, the Moroccans ranked first in terms of inflows - followed by the Algerians in second and the Tunisians in fourth - and held on to that position by 2000 .

11 BLACK (2003) suggests that the analysis of official statistical data be qualified by looking at the legalisation processes of formerly undocumented immigrants and by consultations and interviews with people and organisations working with immigrants and refugees.

12 Between 1991 and 2000, 115,000 Algerians and 164,000 Moroccans acquired French nationality. Of the 84,200 Africans who applied in 2002, 81\% were of North African origin. 
Temporary immigration has been increasingly stimulated, namely by passing new legislation that has led to an increase in the number of foreign students, temporary work permits and seasonal immigrants from third countries ${ }^{13}$. In what regards immigration of a more permanent nature, family reunification, with 77 per cent of new entries from third countries, is currently the main immigration channel into France ${ }^{14}$. Asylum applications increased by 25.4 per cent between 1990 and $2000{ }^{15}$.

In Italy, the foreign-born population amounted to 2.4 per cent in 2000 . Of these, the majority (six out of seven) came from emerging and developing countries; 15.3 per cent of all documented immigrants came from Northern Africa. The immigrant population in Italy nearly doubled between 1985 and 1990, a period in which North African immigration increased exponentially, thus reaffirming the weight of the Moroccan and Tunisian communities ${ }^{16}$. These tendencies were further reinforced in the 1990s: among the documented immigrants, Moroccans ranked first in terms of stocks and second in terms of inflows in 2000 (see Table 1), even though the relative weight of the Tunisians experienced a slight decrease due to the growth in immigration from other regions, such as the Balkans, Southern Asia, Latin America and China.

Following the general European tendency towards discouraging permanent immigration, there has been an increase in the number of short-term permits: tourist and study visas and refugee status, for instance. At the same time, the number of Moroccan and Tunisian workers holding work permits increased by 72 per cent and 75 per cent, respectively, between 1995 and 2000, illustrating the increasing importance of the work permits ${ }^{17}$.

The 1998 immigrant legalisation campaign awarded legal status to $217,000 \mathrm{immi}-$ grants, reflecting upon the stock of foreign citizens and the record of inflows (see Tables 1 and 2). In the previous three legalisation campaigns for undocumented foreign citizens, Moroccans were always the most numerous nationality. However, they ranked third in the 1998 campaign, behind the Romanians and the Albanians. This had very much to do with both the share of undocumented migration from Morocco and with the new migratory dynamics that are gradually turning Italy into a major destination for migratory flows from the Balkan area.

In order to tackle the rise in illegal immigration ${ }^{18}$, the Italian Parliament has passed strict specific legislation, seeking to curb these flows and to prevent immigrants

13 Approximately one half of these permits were granted to Moroccan citizens.

14 In 2000, 21,400 people entered French territory under family reunification provisions: $66.6 \%$ of these were Africans, most of which from the Maghreb.

15 With 39,000 entries, this is the single largest category of temporary immigrants.

16 In 1985, there were 2,600 Moroccan and 4,400 Tunisian immigrants in Italy. By 1990, these figures had increased to 78,000 and 41,200, respectively. Between 1985 and 1990, the Moroccan immigrant community jumped from eighth to first position in the ranking of the most numerous foreign resident communities, while the Tunisians moved up from seventh to fourth. See Table 1 for the changes in the 1990s.

17 The Moroccans are the largest nationality both among the 340,000 foreign workers holding work permits and the 1,011,751 foreign workers registered in the Italian social security system.

18 In 2000, the records kept by the local authorities exceeded by 76,000 the number of foreign citizens holding official central government permits and visas of various kinds. Even though North African immigrants probably account for a small portion of these 76,000 - which correspond mainly to other longer-standing communities -, this gap illustrates the weight of undocumented immigration. 
from overstaying by means of a series of dissuasive and punitive measures ${ }^{19}$. This has taken place within the ambit of a strategy built around the idea of treating undocumented immigrants as criminals - actually, much more so than in the other Southern European countries of immigration ${ }^{20}$. In 2000 , nearly 130,000 people were forced to leave the country - a 15.9 per cent increase from 1999.

In Italy, the acquisition of citizenship by foreigners is much less significant than in France: in 1999, less than 14,000 people acquired Italian citizenship. In turn, family reunification has been on the increase, just like in France: in the year 2000, 20.7 per cent of all permanence permits were granted under family reunification provisions.

In Spain, Algerian residents ranked an insignificant 15th among the foreign resident nationalities in 2000, and Tunisians were even less numerous. It is the Moroccan community that is truly significant, ranking first with 200,000 documented immigrants in 2000. This is largely the reflection of a significant change in the composition of the foreign population in Spain: between 1996 and 2000, immigrants from outside the EU increased from 41 per cent to 60 per cent.

The legalization campaigns of 1985/1986, 1991, 1996, 2000 and 2001 contributed substantially to this growth: over half a million people, 23 per cent of which Moroccans, took these opportunities to acquire legal status. The two latest legalisation campaigns (2000 and 2001), along with the increase in documented labour migration, have raised the total number of documented immigrants to 1,1 million people, or 2.2 per cent of the total population. The weight of the naturalisation processes is in the Spanish case relatively less significant ${ }^{21}$.

With regard to work visas, the available data for 1995 and 1999 illustrate the importance of the Moroccan presence in Spain, since this is the national community that most relies on this kind of permit - Algerians rank a distant ninth.

As in the case of Italy and France, strict punitive legislation has also been passed by the Spanish parliament. The two Laws passed in 2000 have revoked the 1985 legislation and implemented a system based on work permits and quotas. In 2002, a new quota system, defined by activity sector, region and type of labour was put into place. The alleged goal of these measures was to control the flows and to manage them in a manner that is compatible with the regional and national needs, by discouraging the entry of undocumented foreigners, preventing the economic exploitation of immigrants in an

19 The new 2002 Immigration Law has brought on a reduction in the time length of the permits, created mechanisms aimed at making it easier to deport unemployed immigrants, made the non-renewal of the permit entail the loss of all payments to the social security made in the past and created a legal obligation for all foreigners to have their fingerprints taken. Undocumented immigrants caught on Italian territory are prevented from entering the country for 10 years and are liable to being held in custody for 6 to 12 months. Those attempting to re-enter the country after having been expelled can be kept in custody for 1 to 4 years. Asylum applicants who apply after having been detained without documents are kept in custody until their legal process reaches its end.

20 QuASsoli (2002) argues that there is a close link between police practices and immigrant exclusion in Italy and analyses the "criminalisation" of undocumented immigrants. Social alarm arises from the actions of the police and the influence of the media and contributes to the general confusion between the lack of documents on the part of a large number of immigrants, and the criminal activities of certain specific groups.

21 As in the Italian case, naturalization is a relatively unimportant phenomenon in Spain, especially when compared with the French case. Between 1991 and 2000, around 11,000 Moroccans acquired Spanish nationality (see Table 2). 
illegal situation and effectively selecting from amongst foreign workers. However, immigrant workers, whether documented or undocumented, have consistently proven essential for the competitiveness of several Spanish industries, particularly in the primary sector ${ }^{22}$. By migrating in a circular manner between different municipalities and regions, primary sector migrants display some of the most characteristic tendencies of North African immigration in Spain (TERREgrosa, 1994).

The figures mentioned thus far corroborate the idea presented in the previous section, according to which North African immigration to Italy and Spain is a fairly recent phenomenon, and clearly sets it apart from the French case. However, there are relatively significant North African communities in other European countries that are worth a brief mention. In Belgium, there were 142,000 documented Moroccan immigrants in 1990 and 107,000 in 2000, making it the second largest immigrant community in 1990 and the third in 2000 (see Table 1), right behind the French and the Dutch. There was a constant inflow of Moroccans throughout the 1990s, meaning that the decrease in the stock of documented Moroccans was largely a consequence of naturalisation: Moroccans rank first among the non-European nationalities to acquire Belgian nationality. Indeed, after the amendments to the National Code made in 2000, the number of naturalisation processes increased by 155 per cent. The Algerian community in Belgium can not be regarded as insignificant, either, even though it ranked 11th in 1985 and 14th in 2000 .

In the Netherlands, the Moroccans, with 111,000 residents in $2000(160,000$ in 1990) again rank first among the immigrant communities. Moroccans also ranked second in terms of inflows by the early 1990s, dropping to fourth after 1993. This community was also the one to benefit the most from the naturalisation opportunities created in 1999 and 2000. Documented Tunisians, by contrast, were a mere 1,300 in 2000, whereas Algerians were even fewer.

The North African community in Germany is also worth mentioning: in 2002, there were around 80,000 Moroccans, 24,000 Tunisians and 17,300 Algerians. Inflows in 2001 do not display a tendency towards the reversal of these trends: approximately 6,000 Moroccans, 3,000 Algerians and 2,600 Tunisians entered the country. Between 1995 and 2002, nearly 34,600 Moroccans, 12,600 Tunisians and 3,000 Algerians acquired German nationality ${ }^{23}$.

\section{THE CHARACTERISTICS OF NORTH AFRICAN IMMIGRATION FLOWS IN THE PRESENT DAY}

Generally speaking, the recent patterns of the immigration flows from the Maghreb indicate some significant changes over the past thirty years. Faced with increasingly restrictive immigration laws in the traditional receiving countries, North African immigrants have selectively and gradually adapted their migration patterns, increasingly turning to new destinations in Southern Europe, to seasonal labour in low-skilled, labourintensive sectors and to alternative markets for immigrant labour, such as the Persian Gulf countries (MGHARI, 2000).

22 Undocumented workers are indeed essential for Spanish agriculture. Alongside the roughly 25,000 documented foreigners working in this sector by the late 1990s, many others effectively served as "surplus pockets" of workers in an irregular situation (PÉREZ AND LóPEZ-TRIGAL, 1999).

${ }^{23}$ Source: Migration Policy Institute Global Data Center - Germany country profile (taken from http://www.migrationinformation.org/Profiles/ ) 
As the new countries of immigration in turn changed their own legislations, bringing them closer to the ones adopted in the 1970s in France and Northern Europe, the number of undocumented foreigners has consistently increased, as has the reliance upon the family reunification channel - even in countries like Italy and Spain ${ }^{24}$. This has also reflected upon the characteristics of the migratory flows, which have become more and more permanent ${ }^{25}$ : in this day and age, returning to the homeland after years of emigration can at best be considered an unlikely event - if not a myth -, even though it was a central goal for most migrants for many years (GIUBILARO, 1997).

Family reunification has also brought about some changes in the composition of the migration flows from the Maghreb: the proportion of immigrants outside the working age has been on the increase (as has the number of women and children) and the average age of the immigrant population is increasingly lower ${ }^{26}$.

On the other hand, the traditionally low educational levels of the North African immigrants have also experienced an increase. Whenever the family has been in the receiving country for some time, children usually have higher educational levels than their parents. Moreover, over the past twenty years, more and more people have had access to education before the migration process ${ }^{27}$. Other positive changes have also taken place with regard to the social-professional status of the documented immigrants from these countries: the relative weight of white-collar immigrants has consistently increased ${ }^{28}$. In Spain, most North African immigrants start off by working in agriculture, but usually aim to move on to the secondary and tertiary sectors (PÉREZ and LóPEZ TRIGAL, 1999; TERREgrosa, 1994).

Yet another important change has had to do with the spatial origin of the immigrants (within the countries of origin). In the 1970s, most North African immigrants came from rural areas, but the escalating unemployment has pushed up emigration rates in cities as well. MGHARI (2000) highlights the consequences of this new migratory momentum for the Maghreb countries. He, along with other authors, argues that emigration has at least three beneficial effects for the sending societies: a) less pressure on the

24 As has occurred in the French case: by 1999, long-term immigration to France was comprised of the following: 20 per cent labour migrants; 25 per cent refugees; and the rest entered the country under family reunification provisions (UN, 2002).

25 Before the closing of the borders, short-term migratory movements between Northern Africa and Europe were more frequent. However, legal barriers have changed this substantially, making it harder for North African citizens to circulate between the two sides of the Mediterranean: uncertainty as to whether they will be able to re-enter the EU has generally contributed to permanent settlement - what used to be the exception up until the 1980s, has now become the rule (MGHARI, 2000).

26 In France, in the 1980s, the drop in the percentage of males in the immigrant population was quite obvious. Likewise, there have been some significant changes in the structure of the North African families in France: by 1990, 71 per cent of the Moroccans and Tunisians and 66 per cent of the Algerians lived as a couple. Couples with children were already consistently above 50 per cent. The lone male - the classic image of the North African immigrant in France - nowadays accounts for a mere 15 per cent of the Northern African households in France.

27 Between the 1960s and the 1990s, the percentage of immigrants with no education whatsoever at the time of the migration process has dropped from 60 per cent to 15 per cent. Over the same period, the percentage of those having attained secondary or higher education increased from 18.5 per cent to 60 per cent.

28 In France, for instance, immigrant employment in the tertiary sector has increased from $17 \%$ to $41 \%$ between 1975 and 1990 . 
supply side of the domestic labour market ${ }^{29}$; b) the positive effect of the emigrants' remittances upon the balance of payments and the development process in general ${ }^{30}$; and c) human capital accumulation by way of migration ${ }^{31}$.

In the receiving societies, the economic changes of the past few years have considerably weakened the position of the North African immigrants in the labour market: their unemployment rates are well above those of the autochthonous population ${ }^{32}$. Moreover, the increasingly precarious nature of the work contracts has enabled certain companies to exploit immigrant workers ${ }^{33}$, thereby exposing them to chronic work instability and often to poor housing and living conditions in general. Often relying on informal jobs, sometimes filling the positions left vacant by fellow countrymen who have been repatriated, or by documented seasonal workers who have become too expensive as com-pared to undocumented ones, many of these immigrants endure sub-human working and living conditions, some actually reaching homelessness (VALLAT, 1999). While the access to legal permission to remain in the country can protect immigrants from extreme labour precariousness (GIUBILARO, 1997), many seek to improve their chances of upward social mobility by way of naturalization - especially in France -, once they fulfil the legal requirements to do so, at least as long as the bundle of rights contained in the European Commission's concept of civic citizenship (or denizenship) does not fully come into being.

\section{FUTURE DEVELOPMENTS}

Traditional neoclassical migration theory seeks to estimate migration flows as a function of wage differentials between countries ${ }^{34}$, which are in turn expected to reflect a myriad other aspects, including the demographic situation in the sending and receiving countries (CASTLES AND MILLER, 2003). This type of methodology builds on two underlying assumptions: (i) that these phenomena are characterised by "structural stability" (and are solely dependent upon the aforementioned variables); and (ii) that labour as a productive factor is essentially fluid, regardless of other historical, political and institutional considerations (which may bring about flows of varying magnitudes in settings that are essentially similar with regard to wage differentials).

29 The situation of the labour market is one of the central problems of the North African economies. The capacity of these economies to generate enough demand for labour in order to effectively absorb demographic growth has proven clearly insufficient. It is likely that emigration can only marginally help to overcome this problem (GIUBILARO, 1997).

30 It is a well-known fact, however, that changes in the prevalent migration model - namely the temporary vs. permanent vs. transnational nature of the flows - have a crucial impact upon the maintenance of close ties between immigrants and their original communities, especially after family reunification. Other authors, on the other hand, have sought to challenge the view that remittances have an automatically beneficial effect upon the economies of the sending countries - an idea we do not partake of (See GlYTSOS, 2002).

31 i.e., the incorporation of specialized know-how in local development processes by the emigrants upon returning to their homeland, or, in the case of transnational communities (LEVITT, 2001), while in the receiving country.

32 In France, for instance, the unemployment rate among the North African communities reaches $30 \%$.

33 Undocumented immigrants are regarded as flexible, available and highly mobile labour by many employers and as outlaws by the authorities (QuASSOLI, 2002).

34 With varying degrees of subtleness, from considering the costs of the migration process to using unemployment rates to weigh down wage differentials. 
Despite the fact that there are indeed significant correlations between these variables and the magnitude of migratory flows, the truth is that these models have proved particularly poor when it comes to predicting future flows. That, in our view, is largely due to the unrealistic nature of those very assumptions: empirical evidence solidly backs the view that migration is a complex, path-dependent phenomenon that depends upon economic, social and cultural motivations and constraints and which is subject to (as of yet largely unpredictable) structural change. Consequently, attempts at prospective analyses probably have less to gain from such mechanistic approaches than they do from a more modest (middle range) and syncretistic (drawing on economics as well as on other social sciences) approach (see, for example, Bretell and Hollifield, 2000; Peixoto, 2002). In the case at hand, we shall merely try to outline some of the general trends that are likely to arise from the main relevant factors (particu-larly, institutional ones) affecting North African emigration.

In the words of SASSEN (2002), "migration doesn't just fall from the sky". Indeed, it is a social process that is closely linked with other aspects that are characteristic of this phase of the globalisation process, such as the expansion of agro-industry (whereby numerous emerging economies have increasingly turned to export-oriented extensive crops) or the expansion of overseas foreign direct investment - which have brought about the gradual de-structuring of traditional livelihoods and pushed vast rural populations to wage-earning and rural exodus, thereby "reducing the subjective distance between the worker and the potential receiving countries" (id., ibid.; see also Pегхото (2002)).

In the case of the Maghreb, these general trends are visible, for instance, in the growth rates of the urban population ${ }^{35}$, which, as we have seen, are the result of processes that are largely the same as those out of which international migration arises. The potential impact of these processes seems to be far from over (both in the case of the Maghreb and worldwide) and it appears that migratory pressures are likely to intensify in the future ${ }^{36}$. Moreover, one particularly relevant institutional change will take place in the near future that is likely to foster such pressures: the creation of a Euro-Mediterranean Free Trade Area by 2010 - the Barcelona process -, by way of a series of agreements between the EU member states and 12 Mediterranean partners. These agreements aim at the opening up of markets, promotion of investment, industrial cooperation and trade between the European Community and the Mediterranean partners, as well as among the Mediterranean partners themselves, but deliberately leave out migratory flows. In what regards the "management" of migration flows, this measure possibly builds on the assumption that, under certain conditions, international trade and the liberalisation of capital flows are substitutes for migration flows. Ideally, the development sought by that liberalisation ought to curb migratory pressures and increase welfare in both ends of the migration system (GARSON, 1998). However, Solimano (2001) and numerous other authors have pointed out that international trade and investment

35 Between 1960 and 2001, the annual growth rates of the urban population in Morocco and Algeria were consistently above $3 \%$, and only slightly lower in Tunisia (Source: World Bank Development Indicators 2003).

36 Both because of the economic restructuring taking place in these countries and because population growth, largely due to demographic momentum (since the drop in fertility in recent times has indeed been remarkable), will persist for quite some time - the Population Reference Bureau, cited in PIson (2003), makes the following population projections for 2025: 42,8 million in Algeria (as compared to 31,7 in 2003); 39,2 million in Morocco (30,4 in 2003); and 11,6 million in Tunisia $(9,9$ in 2003). 
and international migration are usually positively correlated; complementary rather than substitute phenomena. The combination of "Fortress Europe" and a Euro-Mediterranean Free Trade Area thus seems destined to fail. Migratory pressures will most certainly persist and will probably increase - and the attempt to erect ever-stricter legal barriers to immigration will not only entail greater and greater costs, but also have as their most likely result an increase in irregular immigration ${ }^{37}$.

Going back to the mechanistic forecasting procedures described earlier on, it is worth mentioning that in the specific case of North African migration to Southern Europe, for all the caveats indicated with regard to such techniques, similar conclusions can be drawn. Despite the relative convergence between the two shores of the Mediterranean in terms of per capita income ${ }^{38}$, the truth is that there remains a very considerable absolute gap ${ }^{39}$.

Likewise, over the next few decades, it seems likely that the receiving end of this system will also continue to play a positive effect upon migratory potential. At least, so it seems from the point of view of Southern European societies: ageing and demographic decline, alongside the general increase in the standard of living of the autochthonous population (bringing about labour market segmentation and an increase in demand for flexible and relatively low-skilled labour for secondary, location-specific activities - hotels and restaurants, household and industrial cleaning, construction, agriculture) also seem likely to reinforce migratory flows in the future.

To sum up, our conclusion is that the migratory pressure in this migration system is likely to increase, at least in the next few years, via neoclassical as well as informational and institutional mechanisms, in both the sending and the receiving ends of the system. The scale of this pressure will probably be such that the degree of legal openness to immigration displayed by the EU and its member-states will most likely affect the regular vs. irregular nature of the flows ${ }^{40}$, rather than effectively making it possible for decision-makers in host societies to unilaterally determine their overall volume.

\section{REFERENCES}

37 Arguably, the fact that thousands of North Africans continue to risk their lives to cross the Strait of Gibraltar in pateras, after so many died doing so, is proof to this "inelasticity of migrant supply" argument.

38 The growth rates of per capita GDP in Algeria, Morocco and Tunisia in 2002 (amidst worldwide economic recession) were an estimated 3 per cent, 3.2 per cent e 1.9 per cent, respectively, as compared to 1 per cent, 2 per cent e 0.4 per cent in France, Spain and Italy (Source: CIA World Factbook).

39 Per capita GDP (p.p.p.) in 2001 was US $\$ 6,090$, US $\$ 3,600$ and US $\$ 6,390$ in Algeria, Morocco and Tunisia, respectively; as opposed to US $\$ 23,990$, US $\$ 20,150$ e US $\$ 24,670$ in France, Spain and Italy (Source: World Bank Development Indicators 2003). Curiously enough, all three Maghreb countries are inside Olesen's migration band, the aggregate expression of Martin's migration hump, i.e., the income interval [estimated by OLESEN (2002) as US $\$ 1,500-8,000$ per capita] inside which countries experiencing an increase in income are expected to experience an increase, rather than a decrease, in emigration.

40 With all the ensuing consequences upon the social integration of the immigrants, as well as upon the rights and privileges of both autochthonous and immigrant workers. 
BecK, J. and De MAs, P. (2001) - The Strait of Gibraltar: Europe's Rio Grande?. In KING, De MAs and BECK (eds.) - Geography, Environment and Development in the Mediterranean. Sussex Academic Press, Brighton.

BensÂAd, A. (2002) - Voyage au bout de la peur avec les clandestins du Sahel. Manière de Voir, 62, Paris: $15-20$.

BLACK, R. (2003) - Breaking the Convention: Researching "Illegal” Migration of Refugees to Europe. Antipode - A Radical Journal of Geography, 35(1), Blackwell Publishing, Oxford: 34-54.

Boubakri, H. (2001) - Le Maghreb et les nouvelles configurations migratoires internationales: mobilité et réseaux. Correspondances, 68, Tunes: 8-15.

Bretell, C. and Hollifield, J. (2000) - Migration theory: talking across disciplines. Routledge, London.

CAstles, S. and Miller, M. (2003) - The age of migration: international population movements in the modern world, $3^{\text {rd }}$ edition. The Guilford Press, New York.

Cegarra, M. (2002) - De la flexibilité du travailleur étranger. Manière de Voir, 62, Paris: 47-50

FonSECA, M. L. (2002) - Immigration and spatial change: the Lisbon experience. Studi Emigrazione, XXXIX (145), Roma: 49-76.

GARSON, J.-P. (1998) - Bassin Méditerranéen: échanges et migrations. L'Observateur de l'OCDE, 209, Geneva: 21-24.

GiUbilaro, D. (1997)-Migration from the Maghreb and migration pressures: current situation and future prospects. ILO, Geneva.

GLYTSOS, N. (2002) - The role of migrant remittances in development: evidence from Mediterranean countries. International Migration, 40(1): 6-26.

LevitT, P. (2001) - The transnational villagers. University of California Press, Berkeley

MGHARI, M. (2000) - La migration maghrebine vers l'Europe. CECLR, Bruxelles.

OECD (2003) - Trends in international migration - continuous reporting system on migration, 2002 edition. OECD, France.

OLESEN (2002) - Migration, return and development: an institutional perspective. International Migration, 40(5): 125-150.

Peixoto, J. (2002) - População e Desenvolvimento, Relatório de disciplina para concurso de passagem a professor associado, Instituto Superior de Economia e Gestão, Lisboa.

PÉREZ, V. and LóPEZ-Trigal, L. (1999) - Jornaleros extranjeros en el campo español. Éria, 49: 213-229.

Pison, G. (2003) - Tous les pays du monde (2003). Population \& Sociétés, 392, INED, Paris: 1-8.

QuASsoli, F. (2002)-Making the neighborhood safer: social alarm, police practices and immigrant exclusion (mimeo)

SASSEN, S. (2002) - Les migrations ne surgissent pas du néant. Manière de Voir, 62, Paris: 10-14.

Solimano, A. (2001)-International migration and the global economic order. An overview. World Bank, Washington.

Terregrosa, P. (1994) - L'émigration maghrébine dans l'agriculture espagnole: un effet indirect des politiques d'ajustement structurel?. Options Méditerranéennes, Serie B/8: 135-140.

UN (2002) - International Migration Report 2002. United Nations, New York.

VALLAT, C. (1999) - Clandestinité, économie informelle, logement improbable: vecteur et freins de la mobilité des étrangers présents en Italie. Espaces, Populations, Societés, (2), Paris: 317-327. 